\title{
Detection of Effects of a High Trophic Level Predator, Sorex unguiculatus (Soricidae, Mammalia), on a Soil Microbial Community in a Cool Temperate Forest in Hokkaido, Using the ARISA Method
}

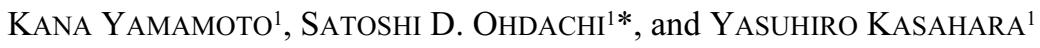 \\ ${ }_{1}^{1}$ Institute of Low Temperature Science, Hokkaido University, Kita-19 Nishi-8, Kita-ku, Sapporo, Hokkaido 060-0819, Japan
}

(Received February 10, 2010-Accepted June 7, 2010—Published online June 30, 2010)

Soil bacteria play important roles as litter decomposers in most terrestrial ecosystems and microbial activity is affected by activities of soil invertebrates. In soil ecosystems of forests in Hokkaido, the long-clawed shrew is an important predator whose preying on soil invertebrates may indirectly affect soil bacterial communities. To estimate indirect top-down effects of shrews on the soil bacterial community, field experiments were conducted using enclosures in which shrews were introduced and removed, and changes in bacterial community composition, species richness, diversity, and evenness were observed using automated ribosomal intergenic spacer analysis (ARISA). Abiotic environmental conditions (ambient temperature, soil temperature, soil moisture content and soil $\mathrm{pH}$ ) were also considered. Bacterial community structure was significantly affected by soil moisture content and soil temperature. The significant causes of the change in bacterial species richness, diversity, and evenness varied among experimental treatments; however, soil moisture tended to have significantly negative effects on these indices in all cases. In the present study, effects of shrews on the bacterial community were not detected.

Key words: top-down effect, shrew, bacteria, soil ecosystem, ARISA

Soil microbes, mainly bacteria and fungi, are essential components of most terrestrial ecosystems, because they are responsible for regulating the decomposition of litter and cycling of nutrients and minerals $(50,55)$. Microbial activity, particularly of soil bacteria, is affected by activities of soil animals $(2,8,24,54)$. Bacterial feeders directly affect the biomass and community structure of bacteria (56). Bacteriafeeding nematodes and/or higher trophic level predators have positive effects on bacterial biomass $(3,12,17)$. Bacterial activity is also promoted by earthworms (Oligochaeta); soil bacteria are often dormant, but become active on passing through the earthworm's gut with organic matter $(9,24,56)$. Additionally, earthworms feed on organic matter in soil and excrete fecal pellets, which are preferred resources for soil bacteria $(15,23,26,57)$. Hence, the feeding activity of earthworms significantly increases bacterial biomass, which raises rates of decomposition and nutrient cycling (13).

In soil ecosystems, there are usually higher trophic level predators classified into soil mega-fauna, which mainly consists of vertebrates preying on soil macro invertebrates such as earthworms, termites, and millipedes (20). Highlevel predators often alter the community structure and biomass of their prey animals. For example, it was demonstrated in a field experiment that salamanders (Plethodontidae, Amphibia) significantly reduced densities of litter-dwelling millipedes, mollusks, coleopteran larvae, and dipteran larvae (58). It is also suggested that shrews (Soricidae, Mammalia) in Eurasian forests consistently consume substantial proportions $(>20 \%)$ of the total soil invertebrate biomass (49). Hence, predation by mega-faunal animals in soil ecosystems

\footnotetext{
* Corresponding author. E-mail: ohd@pop.lowtem.hokudai.ac.jp; Tel: +81-11-706-7474; Fax: +81-11-706-7142.
}

may affect not only directly the biomass of macro-fauna, but also indirectly (1) the community structure of meso- and micro-faunae, (2) bacterial activity, (3) the rate of decomposition of organic matter (litter and carcasses/feces of soil animals), and (4) the nutrient cycling rate.

In soil ecosystem of Hokkaido, northern Japan, the longclawed shrew (Sorex unguiculatus Dobson) is an abundant mega soil animal (32), which mainly eats earthworms and arthropods in litter and soil $(35,36)$. S. unguiculatus has the greatest ability to burrow among Sorex species (and probably of all small mammal species) in Hokkaido (36), digging down to $30 \mathrm{~cm}$ to search for food and making complex burrow systems $(35,60)$. A field experiment was conducted with enclosures and exclosures to investigate the shrews' effects on the soil invertebrate community (30). It revealed that the presence of shrews reduced the biomass of earthworms (Megascorecidae) and spiders (arachnids), but increased that of springtails (collembolans), suggesting a trophic cascade from shrews through spiders to springtails. However, it is unknown whether or not such cascade effects extend to microbes in the soil ecosystem.

In the present study, indirect top-down effects of a high trophic level predator, S. unguiculatus, on bacterial communities were investigated using the same experimental system employed in another study of the top-down effects of shrews on invertebrate communites (30). It should be noted that the present study was conducted under nearly natural conditions rather than the simplified conditions used in microcosm experiments. Most studies of top-down effects on soil bacterial communities have applied simplified ecosystem models such as microcosms in the laboratory, which include only simple interspecific relationships among several prey and predator species (28). These methods do not reflect the com- 
plexity, diversity, and food chain length in natural soil ecosystems. Therefore, the results of such experiments might not reflect the realized relationships among organisms in natural soil ecosystems $(1,19,27,47)$.

Microbial communites are often investigated by amplifying target gene regions from environmental meta DNA, and characterizing the PCR products based on variations in their sizes (e.g., T-RFLP, terminal-restriction fragment length polymorphism; ARISA, automated ribosomal intergenic spacer analysis) and/or physico-chemical properties (e.g., DGGE, denaturing gradient gel electrophoresis; TGGE, temperate gradient gel electrophoresis) $(21,43)$. In the present study, ARISA was applied because of its sensitivity and easiness of replication (18). The aim of the present study is to detect whether or not indirect effects of shrews on bacterial communities occur using ARISA.

\section{Materials and Methods}

\section{Study site}

The study was conducted in the Tomakomai Experimental Forest of Hokkaido University (TOEF: 40 $43^{\prime} \mathrm{N}, 141^{\circ} 36^{\prime} \mathrm{E}$ ) in Hokkaido, northern Japan. The mean monthly temperature ranges from -3.2 to $19.1^{\circ} \mathrm{C}$. Annual precipitation is $1450 \mathrm{~mm}$. Snow cover reaches a depth of $50 \mathrm{~cm}$ from December to March (16), during which soil freezing often occurs. The vegetation is a cool-temperate forest, dominated by oak (Quercus crispula), maple (Acer mono), and linden (Tilia japonica) (29), with a floor of sasa bamboo (Sasa nipponica). The forest is located on the foot of a volcano, Mt. Tarumae, whose last two major eruptions occurred in 1667 and 1739 (minor eruptions sometimes occur even now). The dominant soil is a 2-m deep volcanic ash, consisting mainly of clastic pumice stones and sand, with very shallow $(c a .10 \mathrm{~cm})$ humus $(46,48)$.

In TOEF, major soil animals are earthworms (Haplotaxida), isopods, spiders (Araneae), coleopteran larvae and adults, centipedes (Chiropoda), and ants (Formicidae) as macro soil animals, and mites (Acari) and springtails (Collembola) as meso soil animals (30). As mega soil animals, soricid shrews (Mammalia) and adult salamanders (Hynobius retardatus) are known; the former seem to be much greater in biomass than the latter, according to estimate based on pit-fall trappings (S. D. Ohdachi, unpublished). In Hokkaido, there are 5 species of soricid shrews, Sorex unguiculatus, Sorex caecutiens, Sorex gracillimus, Sorex minutissimus, and Crocidura dsinezumi (38). S. unguiculatus is most dominant throughout Hokkaido (32), although it tends to be second to $S$. caecutiens in the Tomakomai region, probably due to the particular soil type there (32).

\section{Experimental design}

The experiment was designed to manage the presence and absence of shrews by setting enclosure and exclosure (hereafter, simply called "enclosure") plots in a natural forest. Each enclosure was a $15 \mathrm{~m} \times 15 \mathrm{~m}$ square surrounded by a corrugated tin fence ( $1 \mathrm{~m}$ high above and $50 \mathrm{~cm}$ deep below the ground) to prevent the immigration or emigration of shrews and other ground-wandering animals. The area of the enclosure nearly corresponds to the mean home range size $\left(188.3 \mathrm{~m}^{2}\right)$ of $S$. unguiculatus in natural conditions (34). In the introduction treatment, shrews were introduced into an enclosure, while in the removal treatment, they were removed from an enclosure using box traps and pitfall traps (30). In addition, an open control plot of the same area without any experimental treatments was set near the two experimental enclosures. Thus, one unit of the experimental system includes one introduction enclosure, one removal enclosure, and one open control plot. Two experimental units were established, in June 2006 (unit A) and July 2007 (unit B). The distance between the two units was approximately 500 $\mathrm{m}$ and distances between the plots in each unit were 5-10 $\mathrm{m}$.

The shrews (S. unguiculatus) used in the introduction treatment were captured by live-trapping (34) in June, 2007 and 2008, when the young begin to disperse and the population increases in size (33). Trapping was conducted in TOEF or in adjacent areas (Yufutsu Moor, Tomakomai; and Hitsujigaoka, Sapporo) when no shrews were captured in TOEF. For each captured shrew, body weight was measured and age and sex were identified by observing hair wearing and external genital conditions. Shrews were marked by the toe-clipping method (30). Captured shrews were temporarily kept in a cage, but released into enclosures as soon as possible. Before the shrews were released, all small mammals were removed by kill-traps from all enclosures. Since the life span of $S$. unguiculatus in the wild is usually less than 24 months $(33,37)$, the introduction treatment was repeated every year. The survival of the shrews introduced into enclosures was checked by using foot-print methods and an automatic camera system (30) during the experimental period.

\section{Collection of soil samples}

About $30 \mathrm{~g}$ of soil down to a depth of $5 \mathrm{~cm}$, removed of leaf litter and twigs, was collected once a month from each of six sampling points selected randomly within each treatment enclosure or open control plot. The sampling points were 3-10 m apart from each other. Soil sampling was conducted from June 2007 to October 2008. During the winter season from November 2007 to March 2008 , however, sampling was not conducted, since bacterial activity is so low as not to show any substantial changes in community structure during winter in cool-temperate regions $(41,42)$ and soil is frozen during winter in TOEF. Soil samples were packed in plastic bags and kept in a cool icebox. Immediately after arriving at the laboratory, the samples were used for extracting soil DNA and measuring soil $\mathrm{pH}$ and moisture content. Otherwise, they were stored in a freezer at $-30^{\circ} \mathrm{C}$ until the DNA extraction and measuring of soil $\mathrm{pH}$ and moisture.

\section{DNA extraction and purification}

DNA was extracted from about $0.25 \mathrm{~g}$ of soil with a ZR Soil Microbe DNA kit (Zymo Research, Orange, CA, USA). Bead beating was used for the extraction, and purification was conducted according to the manufacturer's instructions. The DNA extracts were eluted in $100 \mu \mathrm{L}$ of the elution buffer included with the kit. These eluted extracts were used as DNA templates for PCR.

\section{ARISA-PCR conditions}

In ARISA-PCR, the ITS (intergenic spacer) region between the small (16S) and large (23S) subunit rRNA genes in the rRNA operon was amplified using the following universal primers for bacteria: S-D-Bact-1522-b-S-20 (5'-TGCGGCTGGATCCCCTCCTT$3^{\prime}$ ) and L-D-Bact-132-a-A-18 (5'-CCGGGTTTCCCCATTCGG-3') (31). This primer set is complementary to positions $1452-1472$ of the 16S rRNA and 133-115 of the 23S rRNA of Escherichia coli (7). For ARISA, the $5^{\prime}$ end of the S-D-Bact-1522-b-S-20 primer was labeled with the phosphoramidite dye 6-FAM (6carboxyfluorescein). The reaction mixture contained approximately $2 \mathrm{ng}$ of DNA template extracted from each soil sample, $10 \times$ PCR buffer $(20 \mathrm{mM}$ Tris- $\mathrm{HCl}$, pH 8.0, $100 \mathrm{mM} \mathrm{KCl}, 0.1 \mathrm{mM}$ EDTA, $1 \mathrm{mM}$ DTT, 0.5\% [v/v] Tween20, 0.5\% [v/v] Nonidet P-40, 50\% $[\mathrm{v} / \mathrm{v}]$ Glycerol), 1.5U of Takara Ex Taq DNA polymerase (Takara Bio, Otsu, Japan), $1.5 \mathrm{mM} \mathrm{MgCl}, 0.2 \mathrm{mM}$ of each dNTP and 0.5 $\mu \mathrm{M}$ of each primer in a final volume of $25 \mu \mathrm{L}$. PCR was carried out in a i-Cycler (Bio-Rad, Hercules, CA, USA). A hot start at $94^{\circ} \mathrm{C}$ for $3 \mathrm{~min}$, was followed by 25 cycles of $94^{\circ} \mathrm{C}$ for $1 \mathrm{~min}, 55^{\circ} \mathrm{C}$ for $30 \mathrm{~s}$, and $72^{\circ} \mathrm{C}$ for $1 \mathrm{~min}$, and the extension of incomplete products for $5 \mathrm{~min}$ at $72^{\circ} \mathrm{C}(43,44)$. The PCR products were checked on $1 \%(\mathrm{w} / \mathrm{v})$ agarose gel by staining DNA with ethidium bromide and visualization over UV light.

The size of the ARISA-PCR products was determined with a DNA analyzer (Prism 3100-avant genetic analyzer, Applied Biosystems, Foster City, CA, USA) in GeneScan mode using a 
36-cm capillary with a POP-4 polymer (Applied Biosystems). $2 \mu \mathrm{L}$ of PCR product was mixed with $9.5 \mu \mathrm{L}$ of deionized formamide and $0.5 \mu \mathrm{L}$ of internal size standard (GeneScan $1200 \mathrm{LIZ}$; Applied Biosystems), and the mixture was denatured at $95^{\circ} \mathrm{C}$ for $5 \mathrm{~min}$ and immediately chilled on ice. Electrophoresis was conducted at $60^{\circ} \mathrm{C}$ and $8 \mathrm{kV}$ with a $100 \mathrm{~min}$ runtime. ARISA fragment size was determined using GeneScan 3.7.1 software (Applied Biosystems).

The output is a matrix of peak intensity for each fragment in the PCR products. The GeneScan software calculates the height of each peak, which is proportional to the quantity of each fragment. It was assumed that the number of peaks represented the bacterial species (OTU) number and that the peak height represented the abundance of each bacterial species $(11,22,25)$.

\section{Cloning and sequencing of ARISA-PCR products}

To confirm whether or not the PCR products of ARISA were actually from the ITS of bacteria, nucleotide sequences of the products were compared with known bacterial ITS sequences cited in DNA databases. An ARISA-PCR product of soil collected from introduction enclosures of unit A in June, 2007 was chosen for cloning as representative. A PCR product was purified by the phenol-chloroform methods. Purified DNA fragments were inserted into vectors, $\mathrm{pPEG}^{\circledR}$-T Easy Vector (Promega, Madison, WI, USA). Competent cells were transformed with pasmid DNA and cultured in Luria-Bertani (LB) medium containing ampicillin, $\mathrm{X}$-Gal (5-bromo-4-chloro-3-indolyl- $\beta$-D-galactopyranoside), and IPTG (isopropylthio- $\beta$-D-galactoside). Using blue-white selection method, 16 colonies were arbitrarily chosen to check the insert. Plasmid DNA was isolated from white clones using a QiaprepSpin Miniprep kit (Qiagen, Hilden, Germany). The cloning site was amplified by PCR using the M13 primer set and it was checked whether or not the cloning of the ARISA-PCR products succeeded. The amplified fragments were sequenced with the DNA analyzer (Prism 3100-avant) using a BigDye Terminator v3.1 Cycle Sequencing kit (Applied Biosystems) and a 50-cm capillary with the POP-6 polymer, following the manufacturer's instructions.

Using the sequences obtained in the present study (DDBJ accession numbers: AB545611-AB545616) and eight bacterial ITS sequences cited in DNA databases (DDBJ/GenBank/EMBL), a neighbor joining (NJ) tree was constructed by MEGA ver. 4.1 software (52) with a substitution model for the maximum composite likelihood and the simultaneous estimation of pairwise distances.

\section{Investigation of abiotic environments}

Ambient temperature, soil temperature, soil moisture content, and soil $\mathrm{pH}\left(\mathrm{H}_{2} \mathrm{O}\right)$ were measured. Ambient and soil temperatures were measured once a month at the time of soil sampling at three points of each experimental or control plot. Moisture content and $\mathrm{pH}$ were measured using part of the soil sampled from 6 points of each plot. For measuring moisture content, $1 \mathrm{~g}$ of soil was used and percent water content was calculated after drying the soil at $105^{\circ} \mathrm{C}$ for $24 \mathrm{~h}$. To determine soil $\mathrm{pH}, 10 \mathrm{~g}$ of soil (fresh mass) was incubated in $25 \mathrm{~mL}$ of distilled water for $1 \mathrm{~h}$ after shaking well and then $\mathrm{pH}$ was measured using a meter (MP225; Mettler-Toledo, Greifensee, Switzerland). Preliminary investigation showed that ambient temperature and soil temperature were positively correlated $\left(R^{2}=0.762, P<0.005\right)$; therefore, ambient temperature was omitted from the analyses. (See Fig. S1 for the monthly changes to abiotic environments in Unit A.)

\section{Statistical analyses}

Fragments of 200 to $1,100 \mathrm{bp}$ were used in analyses, because the bacterial ITS region between the $16 \mathrm{~S}$ and $23 \mathrm{~S}$ subunit rRNA genes varies from approximately169 to $1,200 \mathrm{bp} \mathrm{(31)} \mathrm{and} \mathrm{the} \mathrm{resolution} \mathrm{of}$ the analyzer drops substantially for fragments larger than $1,100 \mathrm{bp}$ (6). The threshold of peak intensity was set at 80 fluorescence units to exclude peaks of noise. Although a fragment length (bp) is a positive integer according to definition, lengths with decimal points (e.g., 255.3, 545.6, etc.) were also observed as errors in the system.
Hence, the peak height of a fragment was calculated including "shoulders" of fragment length with decimal points $(11,51,59)$.

ARISA profiles were used for statistical analyses. The profiles of all 6 samples taken per month from each enclosure or control plot were pooled and mean peak intensity was calculated for each OTU (based on fragment length and henceforth regarded as bacterial species). The vector of mean peak intensities of bacterial species (fragment length) of a month for each experiment was treated as a unit data set, representing a bacterial community in a month in an enclosure or control plot. Peak intensities of ARISA profiles were converted into a table using the RiboSort package of the statistical software $R$ ver. 2.7.2 (53).

Effects of experimental units (differences between units A and B), experimental treatments (the treatments to be divided into two factors: the presence of shrews [+ in introduction enclosure, - in removal enclosure, + in control plot] and the presence of a fence $[+$ in both enclosures, - in control plot]) and abiotic environmental variables (soil temperature, soil moisture content, and soil $\mathrm{pH}$ ) on soil bacterial community composition were analyzed by a permutational multivariate analysis of variance using distance matrices (hereafter called MANOVA although it is not a "true" multivariate analysis of variance) using the vegan package in $R$. Further, effects of the experimental treatments and the abiotic environmental variables on soil bacterial species richness (total number of species), species diversity (Shannon index, $H^{\prime}$ ), and species evenness (Pielou index, $J$ ), widely used as indices of biodiversity $(10,11)$, were analyzed by fitting generalized linear models (GLM) with $R$ ver. 2.7.2. These statistical analyses were conducted using $R$ ver. 2.7.2. The Shannon index $\left(H^{\prime}\right)$ and Pielou index $(J)$ were calculated with Pisces Diversity and Richness Software ver. 3.02 (Pisces Conservation, Hants, UK).

\section{Results}

\section{Identification of DNA fragments amplified by ARISA-PCR}

Five fragments arbitrarily chosen from ARISA-PCR products were cloned and sequenced. Sequences of 5 fragments and 8 published bacterial ITS regions used in the construction of the NJ tree were approximately $300 \mathrm{bp}$ in length. However, after the alignment of sequences, 457 sites with deletions were used for calculations with the pairwisedeletion option. In the NJ tree (Fig. 1), the 5 sequences from the ARISA-PCR products were located close to known sequences of the bacterial ITS.

\section{Community composition}

First, to identify any differences in bacterial community composition between experimental units $\mathrm{A}$ and $\mathrm{B}$, the overall data matrix was tested by MANOVA. There was a significant $(P<0.05)$ difference in composition between the units. Therefore, all analyses were conducted separately in experimental units $\mathrm{A}$ and $\mathrm{B}$.

In unit $\mathrm{A}$, the bacterial community was significantly $(P<0.001)$ affected by soil moisture content, but not by soil temperature, soil $\mathrm{pH}$, the presence of a fence, or the presence of shrews (Table 1). In unit B, soil temperature and moisture content had significant $(P<0.001)$ effects on the community composition, but the other factors did not (Table 1).

\section{Species richness, diversity, and evenness}

Changes in soil bacterial species richness (total number of bacteria) were caused by different factors in the two experimental units (Table 2). The presence of a fence had a significantly $(P<0.05)$ positive effect on bacterial species richness 


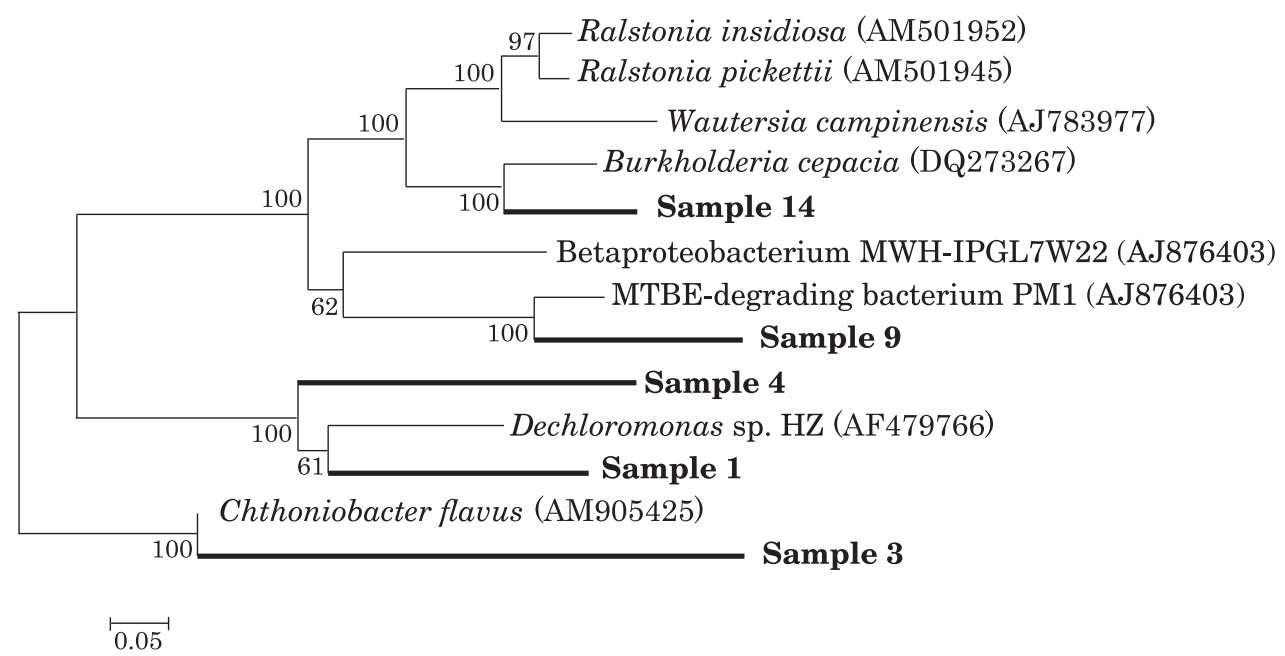

Fig. 1. An unrooted neighbor-joining tree based on DNA sequences of 5 fragments from an ARISA-PCR product (bold) and 8 published bacterial ITS regions. Scale bar indicates 0.05 substitutions per site. Numbers near nodes are bootstrap values (\%) of 1,000 replications. See text for details.

Table 1. Results of the MANOVA for soil bacterial community structure in experimental units A and B, with 5 explanatory factors: experimental treatments (the presence of shrews and the presence of a fence), and abiotic environmental variables (soil temperature, $\mathrm{pH}$, and moisture content)

\begin{tabular}{|c|c|c|c|c|c|c|}
\hline \multirow{2}{*}{ Factor } & \multicolumn{3}{|c|}{ Unit A } & \multicolumn{3}{|c|}{ Unit B } \\
\hline & $\mathrm{df}$ & $F$ statistic & Significance $^{\mathrm{a}}$ & $\mathrm{df}$ & $F$ statistic & Significance $^{\mathrm{a}}$ \\
\hline Soil temperature & 1 & 1.38 & NS & 1 & 3.45 & $* * *$ \\
\hline Soil moisture content & 1 & 3.15 & $* * *$ & 1 & 4.07 & $* * *$ \\
\hline Soil pH & 1 & 0.93 & NS & 1 & 1.43 & NS \\
\hline Presence of a fence & 1 & 1.02 & NS & 1 & 1.14 & NS \\
\hline Presence of shrews & 1 & 0.77 & NS & 1 & 0.68 & NS \\
\hline Residuals & 28 & 0.79 & NS & 32 & 0.72 & NS \\
\hline
\end{tabular}

a *, $P<0.05 ; * *, P<0.01 ; * * *, P<0.001$; NS (no significant difference), $P \geqq 0.05$.

Table 2. Results of GLM for bacterial species richness in experimental units A and B, with 6 explanatory factors: experimental treatments (the presence of shrews and the presence of a fence), and abiotic environmental variables (soil temperature, $\mathrm{pH}$, and moisture content)

\begin{tabular}{|c|c|c|c|c|c|c|}
\hline \multirow{2}{*}{ Factor } & \multicolumn{3}{|c|}{ Unit A } & \multicolumn{3}{|c|}{ Unit B } \\
\hline & Estimate & $z$ value & Significance $^{a}$ & Estimate & $z$ value & Significance $^{\mathrm{a}}$ \\
\hline Soil temperature & $2.69 \times 10^{-3}$ & 0.473 & NS & $1.54 \times 10^{-2}$ & 2.318 & $*$ \\
\hline Soil moisture content & $-4.27 \times 10^{-2}$ & -8.942 & $* * *$ & $-3.31 \times 10^{-2}$ & -6.463 & $* * *$ \\
\hline Soil pH & $2.19 \times 10^{24}$ & 1.074 & NS & $-1.86 \times 10^{27}$ & -2.848 & $* *$ \\
\hline Presence of a fence & $1.81 \times 10^{-1}$ & 2.135 & $*$ & $-1.47 \times 10^{-2}$ & -0.175 & NS \\
\hline Presence of shrews & $1.06 \times 10^{-1}$ & 1.307 & NS & $7.95 \times 10^{-2}$ & 0.922 & NS \\
\hline Intercept & 5.16 & 21.490 & $* * *$ & 4.71 & 16.590 & $* * *$ \\
\hline
\end{tabular}

${ }^{a} P<0.05 ; * *, P<0.01 ; * * *, P<0.001$; NS (no significant difference), $P \geqq 0.05$.

in unit A, but not in unit B (Table 2). Significantly positive $(P<0.05)$ and negative $(P<0.01)$ effects were detected for soil temperature and $\mathrm{pH}$, respectively, only in unit $\mathrm{B}$ (Table 2$)$. Soil moisture content affected significantly $(P<0.001)$ negatively species richness in both units (Table 2$)$. The presence of shrews, however, did not significantly affect bacterial species richness in either unit.

Shannon diversity $\left(H^{\prime}\right)$ was significantly negatively affected by soil moisture content in both experimental units $(P<0.01$, in unit $\mathrm{A}$ and $P<0.05$ in unit B) (Table 3$)$. No other factor (except the intercept) had a significant effect on $H^{\prime}$ '.

The species evenness $\left(J^{\prime}\right)$ of the bacterial community was significantly and negatively affected by soil moisture content in both units $(P<0.01$ in unit $\mathrm{A} ; P<0.05$ in unit $\mathrm{B})$ (Table 4).

The presence of shrews did not affect bacterial community composition, species richness, diversity, or evenness. Meanwhile, soil moisture content affected the community composition and also had significantly negative effects on species richness, diversity, evenness, and total biomass. (See Fig. S2 for monthly changes in species richness, diversity, and evenness.)

\section{Discussion}

The sequences of representative products indicated that the ARISA-PCR fragments were from the bacterial ITS 
Table 3. Results of GLM for bacterial diversity (Shannon's $H^{\prime}$ ) in experimental units A and B, with 6 explanatory factors: experimental treatments (the presence of shrews and the presence of a fence), and abiotic environmental variables (soil temperature, $\mathrm{pH}$, and moisture content)

\begin{tabular}{|c|c|c|c|c|c|c|}
\hline \multirow{2}{*}{ Factor } & \multicolumn{3}{|c|}{ Unit A } & \multicolumn{3}{|c|}{ Unit B } \\
\hline & Estimate & $z$ value & Significance $^{\mathrm{a}}$ & Estimate & $z$ value & Significance $^{a}$ \\
\hline Soil temperature & $1.32 \times 10^{-5}$ & 0.001 & NS & $1.01 \times 10^{-2}$ & 0.581 & NS \\
\hline Soil pH & $4.98 \times 10^{24}$ & 0.953 & NS & $-1.44 \times 10^{27}$ & -1.001 & NS \\
\hline Presence of a fence & $8.36 \times 10^{-2}$ & 0.405 & NS & $1.79 \times 10^{-1}$ & 0.813 & NS \\
\hline Presence of shrews & $1.19 \times 10^{-1}$ & 0.609 & NS & $1.50 \times 10^{-1}$ & 0.682 & NS \\
\hline Intercept & 6.00 & 10.341 & $* * *$ & 5.79 & 8.007 & $* * *$ \\
\hline
\end{tabular}

a $P<0.05 ; * *, P<0.01 ; * * *, P<0.001$; NS (no significant difference), $P \geqq 0.05$.

Table 4. Results of GLM for bacterial evenness in experimental units A and B, with 6 explanatory factors: experimental treatments (the presence of shrews and the presence of a fence), and abiotic environmental variables (soil temperature, $\mathrm{pH}$, and moisture content)

\begin{tabular}{|c|c|c|c|c|c|c|}
\hline \multirow{2}{*}{ Factor } & \multicolumn{3}{|c|}{ Unit A } & \multicolumn{3}{|c|}{ Unit B } \\
\hline & Estimate & $z$ value & Significance $^{\mathrm{a}}$ & Estimate & $z$ value & Significance $^{a}$ \\
\hline Soil temperature & $4.66 \times 10^{-6}$ & 0.002 & NS & $1.55 \times 10^{-3}$ & 0.582 & $\mathrm{NS}$ \\
\hline Soil pH & $7.63 \times 10^{23}$ & 0.954 & NS & $-2.21 \times 10^{26}$ & -1.002 & NS \\
\hline Presence of a fence & $1.28 \times 10^{-2}$ & 0.404 & NS & $2.74 \times 10^{-2}$ & 0.814 & NS \\
\hline Presence of shrews & $1.83 \times 10^{-2}$ & 0.609 & NS & $2.30 \times 10^{-2}$ & 0.682 & NS \\
\hline Intercept & $9.18 \times 10^{-1}$ & 10.343 & $* * *$ & $8.86 \times 10^{-1}$ & 8.005 & $* * *$ \\
\hline
\end{tabular}

a $P<0.05 ; * *, P<0.01 ; * * *, P<0.001$; NS (no significant difference), $P \geqq 0.05$.

(Fig. 1). This analysis suggests most of the PCR products in the present study to be from bacterial ITS regions.

In the present study, abiotic environmental factors, especially soil moisture content, had significant effects on bacterial community composition, species richness, and diversity (Tables 1-3). In addition, negative effects of soil moisture were demonstrated for bacterial species richness, diversity, and evenness (Tables 2-4). Several previous observations demonstrated that bacteria rapidly responded to soil moisture content and that soil moisture positively affected bacterial biomass and activity $(4,14,39)$. The results regarding the effects of soil moisture on bacteria in the present study and previous studies are not contradictory as increases in the activity and biomass of a few species due to a rise in moisture content might result in a monopoly, and consequently low species richness, diversity, and evenness.

In the present study, the presence of shrews did not affect bacterial community composition, species richness, diversity, or evenness (Tables 1-4). There are two possible, though not mutually exclusive, reasons why no top-down effects of shrews on the bacterial community were detected.

First, food-web pathways from shrews (top predators) to bacteria (bottom organisms) in the soil ecosystem would be very complex, mediated by innumerable invertebrate species that themselves are connected with each other in complex ways. Thus, top-down effects from shrews to bacteria, if present, may have been diluted through such long and complex pathways. In most studies where top-down effects on the soil bacterial community were detected $(3,12,17)$, only prey-predator and/or tri-trophic relationships were investigated in simplified model ecosystems consisting of two or three species: e.g., bacteria, bacteria-feeding nema- todes, and the nematodes' predators. In the same field experiment as conducted in the present study, top-down effects were partly observed in some invertebrates and earthworms (30). However, the complex pathways and food web under these more natural conditions might not have brought about obvious effects on the bacterial community. In addition, the observation period of the present study was only two years. In general, it takes a long time for indirect effects on distant organisms to appear in a long food web with complex pathways (40). Therefore, longer monitoring would be needed to detect any effects of shrews on bacterial communities in such a natural ecosystem as manipulated in the present experiment.

Second, ecologically effective spatial scales would differ between shrews and bacteria. The $15 \mathrm{~m} \times 15 \mathrm{~m}$ experimental enclosures were constructed to simulate the natural home range of an individual of $S$. unguiculatus, although several individuals sometimes co-existed in an enclosure. Thus, the enclosure size seems to be adequate to investigate ecological responses of the shrew. However, this plot size might be too large as a unit of observation for bacterial responses, including very heterogeneous microhabitats. The bacterial flora greatly varies among microhabitats with different biophysical conditions on much smaller spatial scales $(5,45$, 61). The 6 samples taken from an enclosure or plot in the present study might be too small a number to represent the average community of bacteria within it. Therefore, effects of shrews on bacteria could have been masked due to large sampling errors.

The present study, however, has proved that the ARISAPCR method is feasible in studies of bacterial communities under natural conditions, detecting some significant effects 
of environmental factors on community structure. For future studies investigating the effects of shrews or top-predators on soil ecosystem functions through changes in bacterial community under natural conditions, the following suggestions are proposed. (I) long-term monitoring of bacterial community and ecosystem functions in the presence or absence of shrews is needed and (II) effective designs for sampling soil from a plot should be established, taking into account ecologically meaningful spatial scales for bacteria.

\section{Acknowledgements}

Thanks to M. J. Toda and M. Fukui for inspiring comments and valuable support. Special thanks to K. Shimada for invaluable support with research techniques for the analysis of soil bacterial communities. T. Namba and R. Kurosawa provided advice for the study and generously answered urgent questions. Sincere thanks also to T. Nishi, A. Kamono, M. Tsutsumi T. Nagane, and M. Shimizu for their assistance in the laboratory. Many people helped constructing enclosure/exclosure pens: S. Kogure, S. Mayumi, R. Miyata, R. Nomura, K. Maeda, M. Fukushima, T. Shirasaki and the technical staff of TOEF. Lastly thanks to members of the Biodiversity Group, Institute of Low Temperature Science for their kindness.

\section{References}

1. Bardgett, R.D., and R. Cook. 1998. Functional aspects of soil animal diversity in agricultural grasslands. Appl. Soil Ecol. 10:263-276.

2. Bardgett, R.D., S. Keiller, R. Cook, and A.S. Gilburn. 1998. Dynamic interactions between soil animals and microorganisms in upland grassland soils amended withsheep dung: A microcosm experiment. Soil Biol. Biochem. 30:531-539.

3. Bardgett, R.D., and K.F. Chan. 1999. Experimental evidence that soil fauna enhance nutrient mineralization and plant nutrient uptake in montane grassland ecosystems. Soil Biol. Biochem. 31:1007-1014.

4. Bell, C., N. Mcintyre, S. Cox, D. Tissue, and J. Zak. 2008. Soil microbial responses to temporal variations of moisture and temperature in a Chihuahuan desert grassland. Microb. Ecol. 56:153-167.

5. Belotti, E., and U. Babel. 1993. Variability in space and time and redundancy as stabilizing priciples of forest humus profiles. Eur. J. Soil Biol. 29:17-27.

6. Brown, M.V., M.S. Schwalbach, I. Hewson, and J.A. Fuhrman. 2005. Coupling 16S-ITS rDNA clone libraries and automated ribosomal intergenic spacer analysis to show marine microbial diversity: Development and application to a time series. Environ. Microbiol. 7:1466-1479.

7. Cardinale, M., L. Brusetti, P. Quatrini, et al. 2004. Comparison of different primer sets for use in automated ribosomal intergenic spacer analysis of complex bacterial communities. Appl. Environ. Microbiol. 70:6147-6156.

8. Coleman, D.C., and D.H. Hall. 2007. Fauna: The engine for microbial activity and transport, p. 163-191. In E. Paul (ed.) Soil Microbiology, Ecology and Biochemistry. Academic Press, Tokyo.

9. Daniel, O., and J.M. Anderson. 1992. Microbial biomass and activity in contrasting soil materials after passage through the gut of the earthworm Lumbricus rubellus Hoffmeister. Soil Biol. Biochem. 24:465-470.

10. Danovaro, R., A. Dell'anno, and A. Pusceddu. 2004. Biodiversity response to climate change in a warm deep sea. Ecol. Letters 7:821828.

11. Danovaro, R., G.M. Luna, A.D. Anno, and B. Pietrangeli. 2006. Comparison of two fingerprinting techniques, terminal restriction fragment length polymorphism and automated ribosomal intergenic spacer analysis, for determination of bacterial diversity in aquatic environments. Appl. Environ. Microbiol. 72:5982-5989.

12. De Mesel, I., S. Derycke, T. Moens, K. Van der Gucht, M. Vincx, and J. Swings. 2004. Top-down impact of bacterivorous nematodes on the bacterial community structure: A microcosm study. Environ. Microbiol. 6:733-744.
13. Elliott, P.W., D. Knight, and J.M. Anderson. 1990. Denitrification in earthworm casts and soil from pastures under different fertilizer and drainage regimes. Soil Biol. Biochem. 22:601-605.

14. Fierer, N., J.P. Schimel, and P.A. Holden. 2003. Influence of drying-rewetting frequency on soil bacterial community structure. Microb. Ecol. 45:63-71.

15. Hassall, M., J.G. Turner, and W.R.M. Rands. 1987. Effects of terrestrial isopods on the decomposition of woodland leaf litter. Oecologia 72:597-604.

16. Hiura, T. 2001. Stochasticity of species assemblage of canopy trees and understory plants in a temperate secondary forest created by major disturbances. Ecol. Res. 16:887-893.

17. Huixin, L., K. Inubushi, and J. Miwa. 2001. Effects of temperature on population growth and $\mathrm{N}$ mineralization of soil bacteria and a bacterial-feeding nematode. Microbes Environ. 16:141-146.

18. Jones, C.M., and J.E. Thies. 2007. Soil microbial community analysis using two-dimensional polyacrylamide gel electrophoresis of the bacterial ribosomalinternal transcribed spacer regions. J. Microbiol. Methods 69:256-267.

19. Kajak, A. 1997. Effects of epigeic macroarthropods on grass litter decomposition in mown meadow. Agr. Ecosys. Environ. 64:53-63.

20. Kaneko, N. 2007. Introduction to Soil Ecology. Biodiversity of Soil Animals and Their Ecosystem Functioning (In Japanese). Tokai Univ. Press, Hatano.

21. Kent, A.D., and E.W. Triplett. 2002. Microbial communities and their interactions in soil and rhizosphere ecosystems. Ann. Rev. Microbiol. 56:211-236.

22. Kent, A.D., S.E. Jones, G.H. Lauster, J.M. Graham, R.J. Newton, and K.D. Mcmahon. 2006. Experimental manipulations of microbial food web interactions in a humic lake: Shifting biological drivers of bacterial community structure. Environ. Microbiol. 8:1448-1459.

23. Kooch, Y., and H. Jalivand. 2008. Earthworms as ecosystem engineers and the most important detritivors in forest soils. Pakistan J. Biol. Sci. 11:819-825.

24. Lavelle, P., C. Lattaud, D. Trigo, and I. Barois. 1995. Mutualism and biodiversity in soils. Plant Soil 170:23-33.

25. Luna, G.M., A. Dell'anno, and R. Danovaro. 2006. DNA extraction procedure: A critical issue for bacterial diversity assessment in marine sediments. Environ. Microbiol. 8:308-320.

26. Milcu, A., S. Partsch, C. Scherber, W.W. Weisser, and S. Scheu. 2008. Earthworms and legumes control litter decomposition in a plant diversity gradient. Ecology 89:1872-1882.

27. Miyashita, T., and S. Niwa. 2006. A test for top-down cascade in a detritus-based food web by litter-dwelling web spiders. Ecol. Res. 21:611-615.

28. Moore, J.C., P.C. De Ruiter, H.W. Hunt, D.C. Coleman, and D.W. Freckman. 1996. Microcosms and soil ecology: Critical linkages between field studies and modeling food webs. Ecology 77:694705.

29. Murakami, M., K. Yoshida, H. Hara, and M.J. Toda. 2005. Spatiotemporal variation in Lepidopteran larval assemblages associated with oak, Quercus crispula: The importance of leaf quality. Ecol. Entomol. 30:521-531.

30. Namba, T. 2008. Top-down cascade effects of shrews on soil ecosystem in a cool-temperate forest. Master's Thesis, Graduate School of Environmental Science, Hokkaido Univ., Sapporo.

31. Normand, P., C. Ponsonnet, X. Nesme, M. Neyra, and P. Simonet. 1996. ITS analysis of prokaryotes, p. 1-12. In A.D.L. Akkermans, J.D. Van Elsas and F.J. De Bruijn (ed.), Molecular Microbial Ecology Manual. Kluwer Academic Publishers, Norwell.

32. Ohdachi, S., and K. Maekawa. 1990. Geographic distribution and relative abundance of four species of soricine shrews in Hokkaido, Japan. Acta Theriol. 35:261-267.

33. Ohdachi, S., and K. Maekawa. 1990. Relative age, body weight and reproductive condition in three species of Sorex (Soricidae; Mammalia) in Hokkaido. Res. Bull. Coll. Exp. For., Facul.Agr., Hokkaido Univ. 47:535-546.

34. Ohdachi, S. 1992. Home ranges of sympatric soricine shrews in Hokkaido, Japan. Acta Theriol. 37:91-101.

35. Ohdachi, S. 1995. Burrowing habits and earthworm preferences of three species of Sorex in Hokkaido. J. Mammal. Soc. Japan 20:85-88.

36. Ohdachi, S. 1995. Diets and abundances of three sympatric shrew species in northern Hokkaido. J. Mammal. Soc. Japan 20:69-83. 
37. Ohdachi, S. 1996. Longevity of captive shrews in Hokkaido. Mammal Study 21:65-69.

38. Ohdachi, S.D., Y. Ishibashi, M.A. Iwasa, and T. Saitoh. 2009. The Wild Mammals of Japan. Shoukadoh, Kyoto.

39. Orchard, V.A., and F.J. Cook. 1983. Relationship between soil respiration and soil moisture. Soil Biol. Biochem. 15:447-453.

40. Pace, M.L., J.J. Cole, S.R. Chapenter, and J.F. Kitchell. 1999. Trophic cascades revealed in diverse ecosystems. TREE 14:483-488.

41. Pettersson, M., and E. Bååth. 2003. Temperature-dependent changes in the soil bacterial community in limed and unlimed soil. FEMS Microbiol. Ecol. 45:13-21.

42. Pietikäinen, J., M. Pettersson, and E. Bååth. 2005. Comparison of temperature effects on soil respiration and bacterial and fungal growth rates. FEMS Microbiol. Ecol. 52:49-58.

43. Ranjard, L., E. Brothier, and S. Nazaret. 2000. Sequencing bands of ribosomal intergenic spacer analysis fingerprints for characterization and microscale distribution of soil bacterium populations responding to mercury spiking. Appl. Environ. Microbiol. 66:5334-5339.

44. Ranjard, L., F. Poly, J. Combrisson, A. Richaume, F. Gourbiere, J. Thioulouse, and S. Nazaret. 2000. Heterogeneous cell density and genetic structure of bacterial pools associated with various soil microenvironments as determined by enumeration and DNA fingerprinting approach (RISA). Microb. Ecol. 39:263-272.

45. Saetre, P., and E. Baath. 2000. Spatial variation and patterns of soil microbial community structure in a mixed spruce-birch stand. Soil Biol Biochem. 32:909-917.

46. Sakuma, T., and F. Sato. 1978. Dynamics of inorganic elements in soils under deciduous forests (In Japanese). Res. Bull. Hokkaido Univ. Forests 44:537-552.

47. Scheu, S. 2002. The soil food web: Structure and perspectives. Eur. J. Soil Biol. 38:11-20.

48. Shibata, H., M. Kirikae, Y. Tanaka, T. Sakuma, and R. Hatano. 1998. Proton budgets of forest ecosystems on volcanogenous regosols in Hokkaido, northern Japan. Water Air Soil Pollut. 105:63-72.
49. Shvarts, E.A., N.V. Chernyshev, and I.Y. Popov. 1997. Do shrews have an impact on soil invertebrates in Eurasian forests? Ecoscience 4:158-162.

50. Singh, J.S., A.S. Raghubanshi, R.S. Singh, and S.C. Srivastava. 1989. Microbial biomass acts as a source of plant nutrients in dry tropical forest and savanna. Nature 338:499-500.

51. Stepanauskas, R., M.A. Moran, B.A. Bergamaschi, and J.T. Hollibaugh. 2003. Covariance of bacterioplankton composition and environmental variables in a temperate delta system. Aqua. Microb. Ecol. 31:85-98.

52. Tamura, K., J. Dudley, M. Nei, and S. Kumar. 2007. MEGA4: Molecular evolutionary genetics analysis (MEGA) software version 4.0. Mol. Biol. Evol. 24:1596-1599.

53. Venables, W.N., D.M. Smith, and The $R$ Development Core Team. 2008. An introduction to $R$. Network Theory Ltd., UK.

54. Wall, D.H., and J.C. Moore. 1999. Interactions underground: Soil biodiversity, mutualism and ecosystem processes. BioScience 49:109-117.

55. Wardle, D.A. 1992. A comparative assessment of factors which influence microbial biomass carbon and nitrogen levels in soil. Biol. Rev. 67:321-358.

56. Wardle, D.A. 2002. Communities and Ecosystems: Linking the Aboveground and Belowground Components. Princeton Univ. Press, New Jersey.

57. Wardle, D.A., R.D. Bardgett, J.N. Klironomos, H. Setala, W.H. Van der Putten, and D.H. Wall. 2004. Ecological linkages between aboveground and belowground biota. Science 304:1629-1633.

58. Wyman, R.L. 1998. Experimental assessment of salamanders as predators of detrital food webs: Effects on invertebrates, decomposition and the carbon cycle. Biodivers. Conserv. 7:641-650.

59. Yannarell, A.C., A.D. Kent, G.H. Lauster, T.K. Krats, and E.W. Triplett. 2003. Temporal patterns in bacterial communities in three temperate lakes of different trophic status. Microb. Ecol. 46: 391-405.

60. Yoshino, H., and H. Abe. 1984. Comparative study on the foraging habits of two species of soricine shrews. Acta Theriol. 29:35-43. 